\title{
DIVINE CHILDREN: THE DAVIDSON SISTERS AND THEIR MOTHER
}

\author{
$B Y$ JESLYN MEDOFF
}

Ms. Medoff is a doctoral candidate in the English Department, Rutgers University

I

n early nineteenth-century America the divine child was a flourishing literary image:

1. In fiction, poetry, and consolatory literature we often find a child marked out from other children by a precocious spirituality and unusual goodness and known by these special signs to be designed for early death. The notion that there were, among ordinary children, extraordinary ones not meant to reach adulthood clearly had immense reconciling power in an era when many children did in fact die young. Such deaths became more bearable when these children were conceived to have been set apart from the first and consecrated to a special mission. ${ }^{1}$

The cult of the divine child was part of a larger trend of sentimentality, parodied in Mark Twain's morbid poetess Emmeline Grangerford, who arrived after the doctor but before the undertaker to write her "tribute" to the dead prodigy. Yet it was taken quite seriously by other literary figures of the time. Lucretia Maria Davidson (1808-1 825) and Margaret Miller Davidson (1823-I 838) were two sisters whose brief lives and longer literary careers, as presented by their mother and prestigious biographers, read like fiction. The tale of these two young victims of consumption and their relationships to their family and literary pursuits seems to be a sentimental novel in itself. It is also a case study in the experiences and education of young American women of the period. The Davidson papers held in the Special Collections of Rutgers University consist of extensive correspondence, notebooks, and various papers of Lucretia, Margaret, their ever-influential mother, Mrs. Margaret Miller Davidson, and other members of the family; many of these papers have never been published. ${ }^{2}$ An examination of some of the material may reveal the unedited voices of the two young

' Nina Baym, Woman's Fiction: A Guide to Novels by and about Women in America, I8201870 (Ithaca: Cornell University Press, 1978), pp. I 5-16.

${ }_{2}$ Unless otherwise cited, all quotations are taken from the Davidson papers at Rutgers University. 


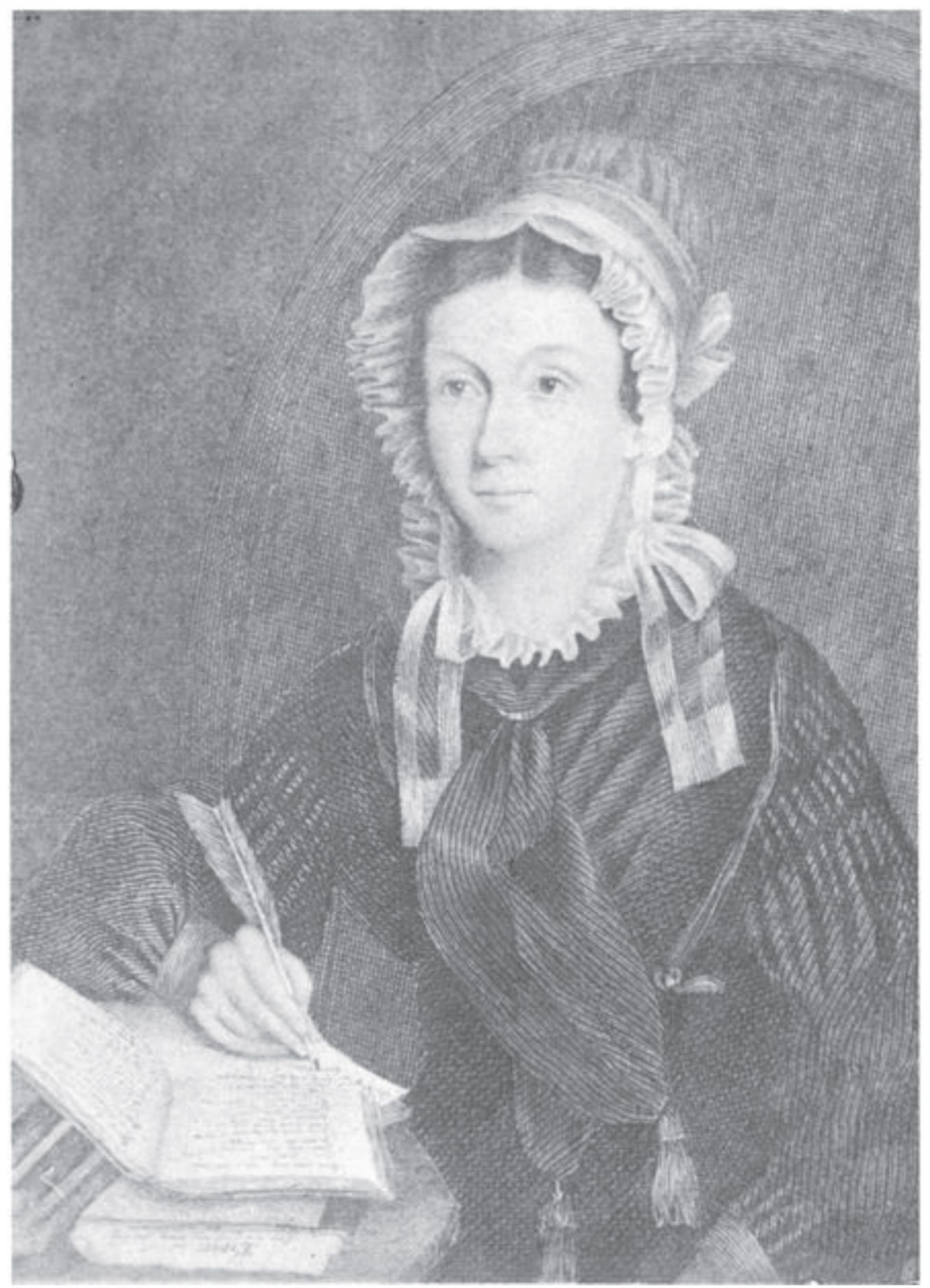

MARGARET MILLER DAVIDSON, MOTHER OF LUCRETIA AND MARGARET. (SPECIAL COLLECTIONS, RUTGERS UNIVERSITY LIBRARIES) 
poets, and explore, in part, the process by which they came to be idolized by a large audience, American and European, as divine children.

Lucretia Maria Davidson was the second daughter of Dr. Oliver Davidson (I 779-I 847) and Margaret Miller Davidson (I 787-I 844) of Plattsburgh, New York. According to all accounts, she was a precocious child, scribbling verses at the age of four. Reticent about her talents, she tried to hide her poems even from her family. Her mother describes Lucretia's reaction, at age eleven, to being discovered in the process of writing:

... she came, blushing \& trembling as if she had been guilty of something criminal; I took her around the neck \& kissing her told her I thought her verses beautiful, \& that I wished she would add a few more to them - She looked at me, as if she doubted my sincerity; but when she was convinced that I was actually serious, she appeared delighted, and seizing the paper, flew off to comply with my request \& the piece was soon completed. I cannot describe to you my feelings when I read it: I caught the dear child to my bosom \& wept with delight - I then told her to persevere; that she should have all the leisure \& instruction, which I could afford her: She was overcome with the force of her feelings - and $\mathrm{Ma}$, may I write \& do you think I can ever write anything good when I get big, \& will you let me, will $P a$ let me, will it be right that I should - I told her that I only wanted her father to see the little production which I then held in my hand \& I was sure he would encourage her. From that moment the cloud passed from her brow, $\&$ she was gay and happy. ${ }^{3}$

The not very well-to-do Davidsons did what they could to keep their promise. Four years later, the congressman Moss Kent, a family friend, financed Lucretia's education at Emma Willard's Female Seminary in Troy, New York. Both at home (Mrs. Davidson was often an invalid) and in Troy Lucretia was surrounded by illness. Her letters home describe alarming cases of influenza and

${ }^{3}$ This account of Lucretia's precocity can be found in a copy book of her verses that contains Lucretia's obituary notices, scraps of notes in Lucretia's handwriting, and copies of her poems in another hand. The pasted-in pages in which this narrative is found are identified as the draft of a letter sent by Mrs. Davidson to "M.K." (presumably Moss Kent, Lucretia's patron) shortly after Lucretia's death. A version of this story also appears in Catherine Sedgwick's biography of Lucretia, Poetical Remains of the late Lucretia Maria Davidson, Collected and Arranged by her Mother: With a Biography by Miss Sedgwick (New York: Clark, Austin and Company, 1850 ), pp. 29-30. Rutgers holds a copy of this work. Further references to this edition will be designated as "Sedgwick, I 850 ." 
fevers sweeping through the school. Lucretia was an ambitious, hard-working student; it is possible that she studied herself ill. ${ }^{4}$ In less than two years, a month before her seventeenth birthday, Lucretia died of tuberculosis.

After her death Mrs. Davidson compiled nearly three hundred of Lucretia's poems, sixty of which were published in Amir Khan, and Other Poems ( I 829) with an introductory biography by Samuel F. B. Morse, President of the National Academy of Design and inventor of the telegraph. ${ }^{5}$ In 1837 Catharine Sedgwick, one of the most popular novelists of the time, contributed a new biography of Lucretia to Jared Sparks' Library of American Biography. In I 84 I the Sedgwick biography was published with more of Lucretia's poems supplied by Mrs. Davidson. ${ }^{6}$ Bound with the poems of her sister Margaret, ${ }^{7}$ this work went through at least fifteen editions in the United States, England, and Germany within the next three decades. ${ }^{8}$ Robert Southey, then Poet Laureate of England, responded to the publication of $A$ mir Khan with a lengthy review in the London Quarterly ( I 829); the Davidson papers include letters from Southey's widow that describe her husband's moist-eyed reaction to the book. He was not alone in his sentiments. William Cullen Bryant was so moved by Lucretia's tragic story that he composed an elegy on her death. Although Edgar Allan Poe insisted on distinguishing between the characters of the Davidson sisters and the quality of their poetry, he too reviewed their works at

4 Sedgwick, 1850, pp. 57-58. Sedgwick used Lucretia's biography as a platform for advocating physical education for young girls.

5 Amir Khan, and Other Poems: the Remains of Lucretia Maria Davidion . . . with a Biographical Sketch by Samuel F. B. Morse (New York: G. \& C. \& H. Carvill, i 829). Further references will be designated by "Amir Khan." A copy of this work is held at Rutgers.

${ }^{6}$ The Poetical Remains of the late Lucretia Maria Davidson, Collected and Arranged by her Mother: with a Biography by Miss Sedgwick (Philadelphia: Lea and Blanchard, 1841).

7 Margaret's poems were first published in The Biography and Poetical Remains of the late Margaret Miller Davidson. By Washington Irving (Philadelphia: Lea and Blanchard, I $84 \mathrm{I}$ ).

${ }^{8}$ Rutgers University holds a copy of the two works bound together, published by Clark, Austin and Company in 1850 , and titled, on the spine, Poetical Works of the Davidson Sisters. A great deal of bibliographical as well as genealogical and biographical information on the Davidson family can be found in the introduction and annotations to Washington Irving's biography of Margaret in Elsie Lee West, ed., Oliver Goldsmith: A Biography / Biography of the late Margaret Miller Davidson, Vol. XVII of The Complete Works of Washington Irving (Boston: Twayne Publishers, I978). See also the entries for Lucretia and Margaret in Lina Maniero, ed., American Women Writers: A Critical Reference Guide from Colonial Times to the Present (New York: Frederick Ungar Publishers Co., 1979) and in Edward T. James et al., eds., Notable American Women 1607-1950 (Cambridge, Mass.: Belknap Press of Harvard University Press, 1971), I, 436-438. 
length and praised the girls' warmth and sweetness. ${ }^{9}$ On both sides of the Atlantic the published lives and works of the Davidson sisters were a critical and popular success.

Neither Lucretia's nor Margaret's work would appeal to modern tastes. Lucretia's poems are Bible tales in verse, odes to fancy, addresses to friends, relatives and her Muse, and, not surprisingly, poems on illness and death. Margaret's poems are similar, except that they are longer, perhaps generally not quite as good, and more of them are dedicated and addressed to their mother. One of the most appealing of Lucretia's poems is the revealing "A Week Before Examination":

One has a head ache, one a cold, One has her neck in flannels roll'd, Ask the complaint, and you are told, Next week's examination.

One frets and scolds, one laughs and cries, Another hopes, despairs, and sighs, Ask but the cause and each replies Next week's examination.

One bans her books - then grasps them tight, And studies morning, noon and night, As though she took some strange delight, In these examinations.

The Books are marked, defaced $\&$ thumb'd, The brains with midnight tasks benumed, [sic]

Still all in that account is sum'd Next week's examinations.

Then speed ye all, and may the smile Of approbation crown your toil, And Hope the anxious Hours beguile Before examination. ${ }^{\text {Io }}$

Margaret was only two when Lucretia died, but she was greatly influenced by her sister's memory and example. Irving cautioned

9 James A. Harrison, ed., The Complete Works of Edgar Allan Poe [New York, 1902], $\mathrm{X}, \mathrm{I} 74-178$.

so This version, dated "Feb. I 825," is taken from the copy book in the Rutgers Davidson papers. The same poem, without the last verse, was included within Sedgwick's biography, which notes "the playful spirit that beams through them [the stanzas] and which seems like sunbeams smiling on a cataract," Sedgwick, i 850, p. 62. 
Mrs. Davidson against "fostering [Margaret's] poetic vein," lest the little girl follow her sister to the grave:

I found Mrs. Davidson fully aware of such a course of treatment, and disposed to pursue it, but saw at the same time that she would have difficulty to carry it into effect; having to contend with the additional excitement produced in the mind of this sensitive little being by the example of her sister, and the intense enthusiasm she evinced concerning her. ${ }^{.1}$

Evidently Margaret could not be prevented from, and perhaps was not really discouraged from, emulating and glorifying her sister. Certainly, she found Lucretia's memory an inspiration for her poetry. Irving excerpted this "tender apostrophe" to the memory of Lucretia in his biography of Margaret:

- One who came from Heaven awhile To bless the mourners here,

Their joys to hallow with her smile, Their sorrow with her tear.

Who joined to all the charms of earth The noblest gifts of heaven,

To whom the muses at her birth Their sweetest smiles had given.

Whose eye beamed forth with fancy's ray, And genius pure and high;

Whose very soul had seemed to bathe In streams of melody.

The cheek which once so sweetly beamed,

Grew pallid with decay,

The burning fire within consumed

Its tenement of clay.

Death, as if fearing to destroy,

Paused o'er her couch awhile;

She gave a tear for those she loved,

Then met him with a smile. ${ }^{\mathrm{I} 2}$

She kept a travel journal when she was ten, describing in lively prose her visits to family and friends in Canada and New York 
state. Irving quoted from it briefly, but most of the journal, held at Rutgers, was not published until I $949 .{ }^{13}$ In language much like that of her mother, Sedgwick, Morse, and Irving, Margaret described her visit to Lucretia's grave (the family was no longer living in Plattsburgh at the time):

... at length we reached Champlain, hurried into the boat and in three hours were landed at our own little village of Plattsburgh, the place of my birth, endeared to me by a thousand tender recollections - here we spent a few days delightfully with our friends. On the $3^{\mathrm{d}} \mathrm{I}$ visited the grave of my departed sister, I cannot describe my sensation while bending over the turf which covered the remains of so much worth and genius, innocence and beauty, here within this dark, damp, and narrow grave, she reposes in silent unconsciousness, this simple monument raised by the affection of a mourning father is all which distinguishes her, from the common mass of mouldering clay by which her remains are surrounded - I plucked a sprig of sweet briar from the grave to present to my friend Mrs. Youle -

She was not sent away to school, as a precaution against her following Lucretia's pattern too closely. As a result, mother and daughter developed an intensely devoted relationship. A holograph draft of a letter by Mrs. Davidson to Anicartha Miller written on the day after Margaret's death at the age of fifteen describes her passing:

\section{Dear dear Anicartha}

$$
\text { Saratoga Nov. } 26^{\text {th }} 183^{8}
$$

It is finished - the redeemed spirit took its flight yesterday morning between four and five o clock. She died in the full possession of her senses frequently expressed her faith in the atonement, and her desire to cast herself upon Jesus - a week before her death she received the Sacrament - after which, her mind became more composed, and the expressions of her faith more lively - a day or two before her death she was agitated with doubts of her salvation - and when I asked her if she had any thing which she desired to be done in case of her death she looked up sweetly, and tremulously replied - dear Mother - when I can read my title clear, to mansions in the skies - I will answer with regard to these worldly matters - and then added Oh Mother I do earnestly desire to live long enough to evince my sincerity in the profession I have made - - on Saturday I asked her if her doubts were removed - Yes dear Mother I am powerless

${ }^{13}$ West, p. 258 and p. 613 and Walter Harding, ed., "Sentimental Journal: The Diary of Margaret Miller Davidson," The Journal of the Rutgers University Library I 3 (December, 1949), 19-24. 
- I can do nothing of myself - I have cast myself wholly on Jesus and I trust that for his dear Sons sake God will pardon my Sins" "All is peace here she added laying her hand on her bosom - her exit was like the going to sleep of an infant - she had been very faint, and oppressed - all at once she spoke "Oh Mother! - dear mother take me in your arms - I did so - she gently dropped her head upon my bosom and expired without a struggle - I closed her dying eyes, and mouth with my own hand - And now dear Anicartha when I have seen her precious remains laid in the Earth - I feel that my work on Earth is finished, and I have only to wait Gods appointed time...

From all appearances, Morse, Sedgwick, and Irving relied heavily on the materials and memoranda supplied by Mrs. Davidson, who was herself a woman of literary talents; her Selections were published a year before her death with a preface by Sedgwick. ${ }^{14}$ Irving described his memoir as "a mere transcript of the records furnished by a mother's heart," though neither his manuscript nor Mrs. Davidson's notes have been found. ${ }^{15}$ The Davidson sisters come to us, then, through the perceptions of a woman who placed a high value on refined sensibilities, a respectable piety, and poetic sensitivity. It may not be unfair, in fact, to assume that Mrs. Davidson not only encouraged her daughters to write, but predetermined that they should. A letter in her handwriting addressed to her sister-in-law, Mrs. Maria Miller, circa 18 I 5 , describes the studies of her eldest child, Anne Elizabeth ( 1 806-1834), when she was nine and Lucretia seven:

Anne Eliza wishes to write to her Aunt, and I intend that she shall very soon - dear little girl she goes to school, and is now very much engaged with her grammar, she is beginning to parse, and tomorrow her instructor says she must commence geography and arithmetic - how grateful to the heart of a Parent, is the rapid improvement of an amiable and lovely child - Anne Eliza has indeed, as yet, been all that a mothers heart could wish, she possesses genius and sensibility, united with an amiable disposition and docile mind - but oh my dear Maria - how incompetent I feel myself to rear the tender plants committed to my care, what an important charge is that of a Mother.....

Mrs. Davidson's description of her "amiable" and "docile" eldest daughter who "possesses genius and sensibility" can easily be applied

${ }^{14}$ Selections from the Writings of Mrs. Margaret Miller Davidson, the Mother of Lucretia Maria and Margaret Miller Davidson . . (Philadelphia: Lea and Blanchard, 1843).

is West, p. 343 . 
to the accepted images of Lucretia or Margaret. This eldest sister married a minister when she was fifteen and moved to Canada, leaving Lucretia behind as the direct object of her mother's devotion and aspirations.

West discusses the "very real possibility that Mrs. Davidson edited Margaret's poems and letters before giving them to Irving," and states, "As a matter of fact, Irving quoted so liberally from Mrs. Davidson's material that the biography ought to be judged as a collaborative work." ${ }^{6}$ She describes Mrs. Davidson as "a mother interested in elevating her daughter to sainthood." $17 \mathrm{Al}$ though West is here discussing Mrs. Davidson's treatment of Margaret's memory, the same can be said of the mother's view of Lucretia. The following is an excerpt from a draft of a letter by Mrs. Davidson to a cousin, dated I 830, describing Lucretia:

... there was a soft and pensive expression in her eyes . . . yet it was brilliant and animated, it was a something which I have never seen in any other eye, and which I fear no painter can touch - . . . the expression of her face spoke a mind raised above the usual pursuits of life and intimately associated with the sacred and the sublime - . . .

Mrs. Davidson's description is an early version of the divine child. In I 85 I Harriet Beecher Stowe would establish the prototype in Little Eva of Uncle Tom's Cabin:

Has there ever been a child like Eva? Yes, there have been; but their names are always on gravestones, and their sweet smiles, their heavenly eyes, their singular words and ways, are among the buried treasures of yearning hearts. In how many families do you hear the legend that all the goodness and graces of the living are nothing to the peculiar charms of one who is not! It is as if Heaven had an especial band of angels, whose office it was to sojourn for a season here, and endear to them the wayward human heart, that they might bear it upward with them in their homeward flight. When you see that deep, spiritual light in the eye, - when the little soul reveals itself in words sweeter and wiser than the ordinary words of children, - hope not to retain that child; for the seal of heaven is on it, and the light of immortality looks out from its eyes. ${ }^{18}$

Actually, Lucretia's real life experiences were not at all sacred or sublime. Shortly after Margaret's birth, she wrote to her sister,

${ }^{16}$ West, p. 63 I and p. xliii.

17 West, p. xlii.

${ }^{18}$ Harriet Beecher Stowe, Uncle Tom's Cabin (New York: New American Library, 1966), p. 283. A similar divine child can be found in Mrs. Stowe's The Pearl of Orr's Island (1 862). 
now Mrs. Townsend, in Canada, describing the conditions of her invalid mother, father, and infant sister. She appears to have been the only healthy member of the family at that time. In the excerpts from this letter, which has never been published before, she emerges as neither divine, delicate, nor saintly, but as a very resourceful, intelligent, and energetic young woman, sounding very much like a real life Jo March:

\section{Plattsburgh May $4^{\text {th }}$ I 823}

My dear Sister

I embrace the first leisure moment to write and let you know how we are. - I have tried faithfully to redeem my pledge - and Mama is now so well that we have little doubt but she will be able to visit you at the time appointed! - She has walked into the Kitchen three or four times, Yesterday Papa got a Carriage, and she rode about half a mile, and returned strengthened, and refreshed. - I have actually pushed her forward with Port Wine, and now Eggs beat in Brandy with Sugar and warm Milk.

Visiting her three dear Children is her constant theme from Morning until Night. - But I fear Anne Eliza that we shall all be disappointed! - If we do not come, - you may be sure of this, - that it is not for want of an inclination. - Papa is very anxious that we should - and is wishing to do every thing in his power to enable us to go, - but you know he has been confined at home a long time, and has had little, or no business, - and of course it is very uncertain whether we can come or not. - At any rate tell your Husband that is [sic] was not because of any deficiency in me, for I certainly have exerted myself in the "good cause." -

Little Margaret still continues to be pale, thin, and feeble, and I am very much afraid that, she will not look as beautiful as I wish she may when you see her. - - However, one thing is true, that her Ladyship's black eyes have proved to be blue! . . . We want to see little Mat very much, but you cannot think what a relief your taking him with you has been to us! - I can now keep the House quiet from 9 'til 5, for Levi is then at school, - and I find that rest is essential to Ma's recovery. -

... Levi says $\mathrm{Mr}$. Townsend told him he might come in Io days from the time you left here, - he has counted every Day regularly and says he believes it will be the best plan for him to take the Steam Boat in 3 days, and start for the Manor. He is really getting to be quite a good Boy. -

William was here yesterday, and admitted into the Sick Room (I should rather say "Pressure Chamber.") He brought with him a young gentleman from Salem. - his name is Powers. - I suppose you heard William say one Evening, when he was trying to beat Stenography into my stupid cranium, - that he became acquainted 
with a young Gentleman while at Salem, who in one Evening taught him all he then knew of it. - He brought recommendations from some very distinguished Gentlemen, - He intends, if he can get encouragement to give Lessons in Stenography. He will commence tomorrow evening, at the Academy, and continue them for I I Evenings, in which time he can give the pupil a perfect knowledge of the art! . . William is very anxious that I should learn, - but I don't think it will be possible. - He has 3 dollars for 6 lessons. -

$\mathrm{He}$ is very young, - only $\mathrm{I} 5$, - and Ma says he's very very handsome. - but William was constantly dodging round him, like a Butterfly over a Rose, - so I could only get a chance to peep at his Nose! - how provoking! -

Mrs DeLord returned on the Evening of the Day in which you left us. - Mary Smith accompanied her from New York and will spend the Summer with us. - She regrets your leaving here before she had an opportunity of seeing you. -

I cannot tell you all she says of her visit to the great emporium of wit wealth, beauty Learning and Fashion, - However I will tell you all I can remember when I see you. - You know I have such an excellent Memory! -

I dont know that you can read this, - you know I write just as it comes easiest, to you, or to any one else. - The Babe has been screaming and I written [sic] this "between showers." - The dear little thing has been quite ill today however she is now much easier. - I hope Ma will be soon able to hold her 〈? $\rangle$ soon. - Mrs. Bailey is now quite well, - she walks all round the village, and had rode out several times. -

I must bid you good Night for I must take care of my patient, and get her asleep. - Give 20 kisses apiece to Mat and Polly and tell them we shall give them the other half when we come! - That [sic] a long letter! I scarcely dare look back upon it! - A thousand dark forms rise in array before me! - but they are phantoms of my own creating - Good Night! - Good Night! - Give my love with Ma's to your Father and Mother, - and Husband. - Good night Sister, Good Night Brother!

yours ever affectionately

L M Davidson

Mrs A E Townsend

$$
\begin{aligned}
& \text { good night my dear children your } \\
& \text { affectionate Mother M D - }
\end{aligned}
$$

P S After I had finished my letter Ma thought she must bid you Good Night I think you will hardly recognize her trembling handwriting. - 
The most moving of all Lucretia's poems is the one she is said to have written on her deathbed. It was published under the title "The Fear of Madness," and suggests the tensions experienced by a young woman writer struggling against her own unladylike imagination:

There is something which I dread

It is a dark, a fearful thing,

It steals along with withering tread,

Or sweeps on wild destruction's wing.

That thought comes o'er me in the hour

Of grief, of sickness, or of sadness;

'Tis not the dread of death - 'tis more,

It is the dread of Madness.

Oh! may these throbbing pulses pause,

Forgetful of their feverish course;

May this hot brain, which burning, glows

With all a fiery Whirlpool's force,

Be cold, and motionless, and still,

A tenant of its lowly bed,

But let not dark delirium steal

(Unfinished) ${ }^{19}$

As the critic Cheryl Walker has noted, "it is rare to find a personal poem on the fear of madness among nineteenth-century men . . . given the inevitable pressures felt by women like Davidson who were torn between art and convention, ... the fear of madness ... was one of the less pleasant side-effects of trying to project a self into the world." ${ }^{20}$

An unabridged, unsentimentalized story of this intriguing young girl and her family remains to be written. The gap between the divine child and the real child is unexplored territory that promises to be valuable not only to historians and literary scholars, but to all concerned with the realities and mythologies of women's lives.

"Amir Khan, pp. 170-171. This poem also appears in the copy book, with the heading "Written during her last illness, \& with a pencil, while sitting in bed."

${ }^{20}$ Cheryl Walker, The Nightingale's Burden: Women Poets and American Culture Before 1900 (Bloomington: Indiana University Press, I982), p. 84. 